\title{
Comparison of Water Resource Management Programs: An Algae Action Threshold Level Approach
}

\author{
West M. Bishop ${ }^{1,2^{*}}$, Ben E. Willis ${ }^{1}$ \\ ${ }^{1}$ SePRO Research and Technology Campus, 16013 Watson Seed Farm Rd. Whitakers, NC, USA \\ ${ }^{2}$ Department of Crop and Soil Sciences, North Carolina State University, Raleigh, NC, USA \\ Email: *westb@sepro.com
}

How to cite this paper: Bishop, W.M. and Willis, B.E. (2017) Comparison of Water Resource Management Programs: An Algae Action Threshold Level Approach. Open Journal of Applied Sciences, 7, 31-41. https://doi.org/10.4236/ojapps.2017.72003

Received: December 13, 2016

Accepted: February 7, 2017

Published: February 10, 2017

Copyright (c) 2017 by authors and Scientific Research Publishing Inc. This work is licensed under the Creative Commons Attribution International License (CC BY 4.0).

http://creativecommons.org/licenses/by/4.0/

\section{(c) (i) Open Access}

\begin{abstract}
Water resource management programs designed to control nuisance algal infestations have historically been dominated by reactive approaches. With increased regulatory scrutiny regarding algaecide use, data regarding efficacy of integrated management approaches are needed. This research outlines an efficient method of comparing management programs based upon exceeding designated algae action threshold levels (AATL) in pond systems. Phosphorus mitigating technologies were specifically evaluated as phosphorus had been indicated in supporting many nuisance algal types/densities. The objectives of this research were to evaluate pond management programs in terms of action thresholds exceeded, number of reactive algaecide treatments and algaecide amount required to maintain ponds below AATL. This research compared management programs consisting of: 1) Copper sulfate; 2) SeClear Algaecide and Water Quality Enhancer; and 3) Phoslock phosphorus binding technology plus SeClear (as needed). Water and algae samples were analyzed every two weeks over two growing seasons on replicated research ponds and compared with designated AATL parameters. If an AATL was exceeded, then a reactive algaecide treatment was implemented for the corresponding water body. Ponds managed by copper sulfate alone exceeded a greater amount of AATL and required a significantly greater $(\mathrm{P}<0.05)$ amount of reactive algaecide treatments to maintain control (average 6.5 annually) whereas SeClear and Phoslock plus ponds required 4.3 and 1.8 treatments, respectively. The average amount of copper applied to maintain ponds below AATL was $1414 \mathrm{~g}$ with copper sulfate whereas copper amendments were significantly decreased with SeClear $(830 \mathrm{~g})$ and even further with Phoslock plus management programs (342 g). Additionally, management programs incorporating nutrient mitigation required fewer treatments and less copper in year two of the program. This research provides valuable information for water resource managers to
\end{abstract}


evaluate integrated approaches to water resource management in terms of social, economic, operational and regulatory viewpoints.

\section{Keywords}

Water Resource Management, Algal Bloom, Action Threshold, Phosphorus, Copper

\section{Introduction}

Water resource management in pond systems is often based on promoting aesthetic quality, although can include other critical usages such as preservation of recreational activities, fisheries production and quality/usability of water for irrigation [1]. As nuisance and noxious algal blooms are increasingly impacting water resources throughout the world [2] [3], a paralleled demand for efficient solutions has arisen. Furthermore, as regulatory scrutiny has intensified, more research is needed on new, integrated and holistic pond management programs [4]. Management can include both proactive techniques (e.g. nutrient mitigation) and reactive strategies (e.g. algaecide applications). Since a common management program includes periodic algaecide applications upon achieving nuisance algal biomass levels, recent regulations have mandated consideration (and implementation where appropriate) of other management approaches. Since prevention is a key component of advanced management goals, and a decrease of algaecide inputs is desired, data are needed to compare the effectiveness (cost and efficacy) of different management approaches that maintain acceptable levels of algae while employing both preventative and (if needed) reactive control measures.

The National Pollutant Discharge Elimination System Pesticide General Permit [4] has stated that action thresholds should be set for instigating a chemical algal management application. Management involving algaecides alone may only address the symptom (algal bloom achieving the action threshold) and not address underlying cause of these blooms or take steps to offset additional rapid re-growth to nuisance levels. Additionally, as the United States Environmental Protection Agency (USEPA) Re-Registration Eligibility Decision on Copper has mandated a 14-day minimum interval between on copper algaecide treatments, management strategies are needed that provide duration of control equal to or greater than 14 days. Algae action threshold levels (AATL) are based on the extent of algal growth necessary to preserve the desired uses of the system. With diverse algal types and growth forms that can impede water uses differently, multiple AATL are often needed to adequately maintain the specific water resource objectives (e.g. drinking, irrigation, recreation, aesthetics, and ecological integrity). By establishing AATL, management programs can be compared based on maintaining ponds below specific action thresholds through time. Strictly reactive algal management approaches may require continuous inputs (due to 
re-growth and exceeding an action threshold). Integration of proactive management may decrease the dominance of nuisance algal types (mat/scum formers, toxin producing cyanobacteria, etc.) and re-growth potential, thus, requiring less reactive management to maintain ponds below designated AATL. More research is needed regarding efficient comparison of pond management programs in order to allow water resource managers to make informed decisions using scientifically defensible data on predicted efficacy, economic viability, and ecological integrity.

Cyanobacteria, in particular, have garnered increased awareness in ponds due to the risks and obviation of water resource uses associated with their presence. Cyanotoxins (e.g. hepatotoxins, neurotoxins, dermatitis toxins) are more rampantly being studied due to the documented impacts to pets, livestock, humans and other organisms external to the water resource [5] [6] [7]. Additionally, some cyanotoxins can negatively impact fish and invertebrate health and other structural characteristics of cyanobacteria may decrease productivity of the system with less energy flow up the food chain [8] [9] [10]. Pond systems afflicted with cyanobacteria often require strategic management to create a safe and usable resource. Excessive phosphorus inputs and decreased nitrogen-to-phosphorrus ratios have, in part, significantly increased the frequency and distribution of toxin-producing cyanobacterial blooms [11] [12] [13]. Limiting phosphorus availability can be an important factor in preventing cyanobacterial presence and dominance [14]. Pond management programs that incorporate phosphorus mitigation can hypothetically decrease the degree of cyanobacteria infestation (e.g. density, duration) and concomitantly offset intensity of reactive management.

Copper sulfate pentahydrate has been historically used to reactively manage algae in pond systems [15]. However, recent innovations in phosphorus mitigating technologies may provide more efficient and sustainable avenues to manage ponds. Phoslock ${ }^{\oplus}$ (registered trademark of Phoslock Water Solutions, Ltd.; not a registered algaecide) consists of a patented lanthanum (5\%) modified bentonite clay formulation that is strictly designed to remove bio-available phosphorus from water and sediments [16] [17]. An additional product recently registered consists of $4.2 \%$ copper combined with a water quality enhancer (SeClear ${ }^{\circledR}$ Algaecide and Water Quality Enhancer; SePRO Corporation; USEPA registration No. 67690-55; patent pending) and is the only product that provides both effective algaecidal activity (i.e. reactive) and is formulated to remove phosphorus from the system (i.e. proactive). There are no water use restrictions following application of Phoslock or SeClear and both are additionally approved for use in potable water sources.

Since water resource management is multi-dimensional in space and time, simply comparing costs and short-term effects of a single application event would not be adequate to understand the overall impact to the water resource or cost of management. By addressing the underlying cause of many negative water quality issues (phosphorus accumulation and inputs), long-term benefits to water quality can be observed. In this study, we compare water resource management 
techniques through time that employ both algaecidal activity as well as phosphorus removal in order to evaluate the long-term benefits of integrated management approaches, in terms of algaecide loading and operational cost. The overall objective of this research was to compare a strictly reactive algal management approach with programs incorporating proactive techniques to maintain ponds below designated AATL and ensure functionality of the water resource. The specific objectives of this research were: 1 ) to compare water quality parameters and algal assemblage composition and densities between three treatment programs, and 2) to compare amount of action thresholds exceeded, number of reactive treatments required, and copper input needed to maintain ponds below AATL over a two-year period between three treatment programs.

\section{Materials and Methods}

\subsection{Study Site Description}

Replicated research ponds (0.04 hectare surface area and average depth of 1.2 meters) at the SePRO Research and Technology Campus (Whitakers, NC) were used for this experiment $\left(36^{\circ} 07^{\prime} 35.34^{\prime \prime} \mathrm{N} ; 77^{\circ} 47^{\prime} 37.49^{\prime \prime} \mathrm{W}\right)$. Ponds designated as Numbers 1, 7, 8, 9, 10 and 14 were selected for this study based on similarity in background water characteristics, water volume, water input dynamics (watershed, evaporation and seepage) and historic algal assemblage. If pond water levels fell below $85 \%$ of full pool, they were filled with similar designated reservoir water.

\subsection{Treatment Programs}

Three treatments consisting of replicated research ponds were randomly assigned. The three treatment programs included: 1) copper sulfate applications upon achieving the AATL, 2) SeClear applications upon achieving the AATL, and 3) an initial Phoslock application followed by SeClear applications upon achieving the AATL. The copper sulfate only ponds were used as a reference to represent typical pond management programs that do not incorporate nutrient mitigation. Experiments were initiated with treatments on all ponds at the start of the growing season (i.e. early June) regardless of whether an AATL was exceeded. The Phoslock amount added was based on a Phoslock to total phosphorus (in the water column) ratio of 100:1 mass/mass (1:1 La:P molar ratio [18]) and was split between two scheduled applications each year (experiment initiation and mid-summer). The average Phoslock amount added per hectare was equivalent to $45 \mathrm{~kg}$ (100 pounds). When reactive applications were needed, the concentration applied would be equivalent to $0.4 \mathrm{ppm}$ copper for the entire pond volume (195 grams of copper added as $3.79 \mathrm{~L}$ of SeClear or 772 grams of $\mathrm{CuSO}_{4} \cdot 5 \mathrm{H}_{2} \mathrm{O}$ ) and applied to approximately one half of the pond water volume. If the same AATL was increasingly exceeded at a subsequent sampling event then a copper rate of $0.8 \mathrm{ppm}$ copper would be applied to that pond with the corresponding product. 


\subsection{Action Threshold Levels and Sample Analysis}

Ponds were monitored every two weeks from the beginning of June through the end of September over two growing seasons. Samples were taken randomly from four sites throughout each pond and homogenized to attain a single composite sample. Each pond was treated individually to compare variability between replicates. All samples were transferred to the SePRO Research and Technology Campus accredited laboratory (ISO 17025:2005; Whitakers, NC) for processing. Water quality parameters were collected and measured according to Standard Methods with documented quality assurance/quality control parameters and included: $\mathrm{pH}$, dissolved oxygen, temperature, alkalinity, chlorophyll $\alpha$, Secchi depth, total nitrogen, turbidity, and algal assemblage composition and densities ([19]; Table 1). Action thresholds for these pond systems were designed based on conservative levels that negatively impact typical pond uses and to proactively avoid severe algal infestations. See Table 2 for a list of parameters that each account for an AATL, which, upon exceeding, trigger a reactive algaecide application.

\subsection{Statistics}

A Mann-Whitney Rank Sum Test ( $\alpha=0.05$ ) was used to discern differences between ponds treated with the same program in the same year, and differences between pooled data from the same program for different years (assuming no difference between ponds treated with the same program). An ANOVA and Student Newman-Keuls Method ( $\alpha=0.05)$ were used to discern differences between AATL exceeded, number of reactive treatments and mass of copper

Table 1. Description of water quality parameters evaluated and analytical methods used to measure.

\begin{tabular}{|c|c|c|c|}
\hline $\begin{array}{l}\text { Water Sample } \\
\text { Parameter }\end{array}$ & $\begin{array}{c}\text { Measurement } \\
\text { Detection Limit }\end{array}$ & Units & $\begin{array}{l}\text { Method } \\
\text { Description }\end{array}$ \\
\hline $\mathrm{pH}$ & 0.01 & SU & Calibrated Meter \\
\hline Alkalinity & 2 & $\mathrm{mg} \cdot \mathrm{L}^{-1} \mathrm{CaCO}_{3}$ & $\begin{array}{l}\text { Discrete Analyzer } \\
\text { (Konelab Aqua 20) }\end{array}$ \\
\hline Hardness & 2 & $\mathrm{mg} \cdot \mathrm{L}^{-1} \mathrm{CaCO} 3$ & $\begin{array}{l}\text { Discrete Analyzer } \\
\text { (Konelab Aqua 20) }\end{array}$ \\
\hline Conductivity & 0.1 & $\mu \mathrm{S} \cdot \mathrm{cm}^{-1}$ & Calibrated Meter \\
\hline Dissolved Oxygen & 0.1 & $\mathrm{mg} \cdot \mathrm{L}^{-1}$ & Calibrated Meter \\
\hline Turbidity & 0.1 & NTU & Calibrated Turbidi meter \\
\hline Chlorophyll $\alpha$ & 1 & $\mu \mathrm{g} \cdot \mathrm{L}^{-1}$ & $\begin{array}{l}0.45 \mu \mathrm{m} \text { Filter, Buffered } \\
\text { Acetone, Fluoro meter }\end{array}$ \\
\hline Total Phosphorus & 1 & $\mu \mathrm{g} \cdot \mathrm{L}^{-1}$ & $\begin{array}{l}\text { Discrete Analyzer } \\
\text { (Konelab Aqua 20) }\end{array}$ \\
\hline $\begin{array}{l}\text { Free Reactive } \\
\text { Phosphorus }\end{array}$ & 1 & $\mu g \cdot L^{-1}$ & $\begin{array}{l}\text { Discrete Analyzer } \\
\text { (Konelab Aqua 20) }\end{array}$ \\
\hline $\begin{array}{l}\text { Total N (TKN + } \\
\text { nitrates/nitrites) }\end{array}$ & 0.02 & $\mathrm{mg} \cdot \mathrm{L}^{-1}$ & Calculation \\
\hline
\end{tabular}


applied between the three treatment programs (copper sulfate, SeClear, and Phoslock plus SeClear; $\alpha=0.05$ ). All data were analyzed using SigmaPlot ${ }^{\oplus} 12.3$ [20].

\section{Results and Discussion}

\subsection{Action Threshold Levels}

The cyanobacterial cell density AATL parameter was exceeded the greatest throughout this study across all treatments. In year one, copper sulfate exceeded the cyanobacterial threshold the most (average of 56\% of sampling events), whereas SeClear and Phoslock plus programs exceeded the cyanobacterial cell density parameter for $44 \%$ and $19 \%$ of sampling periods, respectively. In year two, a similar amount of sampling events for both copper sulfate and SeClear exceeded the cyanobacterial cell density AATL (i.e. 30\%), whereas Phoslock plus SeClear only exceeded on $11 \%$ of sampling events. The total number of times this action threshold was exceeded (over two years) was 15 for copper sulfate, 13 for SeClear, and 5 for Phoslock plus programs, resulting in the Phoslock plus program achieving significantly less cyanobacterial AATL than the copper sulfate or SeClear programs $(P=0.014)$. The overall intensity of the cyanobacterial infestations (i.e. cell density) was greater in the copper sulfate treated ponds in year one and higher for the SeClear treated ponds in year two. SeClear treatments provided greater control of cyanobacteria post-treatment as measured at subsequent sampling events. Copper sulfate ponds increased in cyanobacterial densities following application on four separate sampling periods (Figure 1). These data suggest SeClear is a more effective cyanobactericide than copper sulfate based on the degree of control and decrease of cyanobacterial re-growth rates post-treatment. Reference [21] found phosphorus to be a key component

Table 2. Designation of algae action threshold levels (AATL) that when exceeded would trigger a corresponding reactive algaecide application.

\begin{tabular}{|c|c|c|c|}
\hline Parameter & $\begin{array}{l}\text { Action } \\
\text { Threshold Level }\end{array}$ & Units & Description \\
\hline $\begin{array}{l}\text { Total algae cell } \\
\text { density }\end{array}$ & 100,000 & Cells $\cdot \mathrm{mL}^{-1}$ & $\begin{array}{l}\text { Algae dispersed in the water column, } \\
\text { independent of classification }\end{array}$ \\
\hline $\begin{array}{l}\text { Blue-green } \\
\text { algae cell density }\end{array}$ & 10,000 & Cells $\cdot \mathrm{mL}^{-1}$ & $\begin{array}{l}\text { Cyanobacteria cells only, even if the } \\
\text { above overall algae density is not met }\end{array}$ \\
\hline $\begin{array}{l}\text { Green algae mat } \\
\text { coverage }\end{array}$ & $5 \%$ & $\begin{array}{l}\text { Surface or benthic } \\
\text { area pond } \\
\text { coverage }\end{array}$ & $\begin{array}{l}18.6 \mathrm{sq} \mathrm{m} \text { ( } 200 \mathrm{sq} \text { feet) visible area } \\
\text { covered with green algae (or other } \\
\text { non-blue green algae types) }\end{array}$ \\
\hline $\begin{array}{l}\text { Blue-green algae } \\
\text { mat coverage }\end{array}$ & $2.5 \%$ & $\begin{array}{l}\text { Surface or } \\
\text { benthic area pond } \\
\text { coverage }\end{array}$ & $\begin{array}{l}9.3 \mathrm{sq} \mathrm{m}(\sim 100 \mathrm{sq} \text { feet }) \text { coverage with } \\
\text { cyanobacteria as dominant biomass of } \\
\text { mat }\end{array}$ \\
\hline $\begin{array}{l}\text { Blue-green algae } \\
\text { scum coverage }\end{array}$ & $2.5 \%$ & $\begin{array}{l}\text { Surface area } \\
\text { pond coverage }\end{array}$ & $\begin{array}{l}9.3 \text { sq m ( 100 sq feet) coverage with } \\
\text { cyanobacteria as dominant component } \\
\text { of accumulated surface scum }\end{array}$ \\
\hline $\begin{array}{l}\text { Chlorophyll } \alpha \\
\text { concentration }\end{array}$ & 20 & $\mu g \cdot \mathrm{L}^{-1}$ & $\begin{array}{l}\text { Measured in homogenized planktonic } \\
\text { water sample }\end{array}$ \\
\hline Secchi Depth & 45.7 & $\mathrm{~cm}$ & 3 point average \\
\hline
\end{tabular}


in copper detoxification by algae. Simultaneous phosphorus removal with a copper exposure may result in increased algaecidal activity as observed in this study. Furthermore, fertilized algae were less susceptible to copper exposures than without fertilization [22] [23]. Addressing nutrients can be critical in altering the efficacy of a copper treatment.

Chlorophyll $\alpha$ comprised the second greatest AATL exceeded that consequently instigated reactive algaecide treatments. The total number of times this AATL was exceeded (over two years) was 15 for copper sulfate, 6 for SeClear, and 5 for Phoslock plus programs (Figure 2). Interestingly, there was a significant decrease in the chlorophyll $\alpha$ AATL achieved between the first year (5

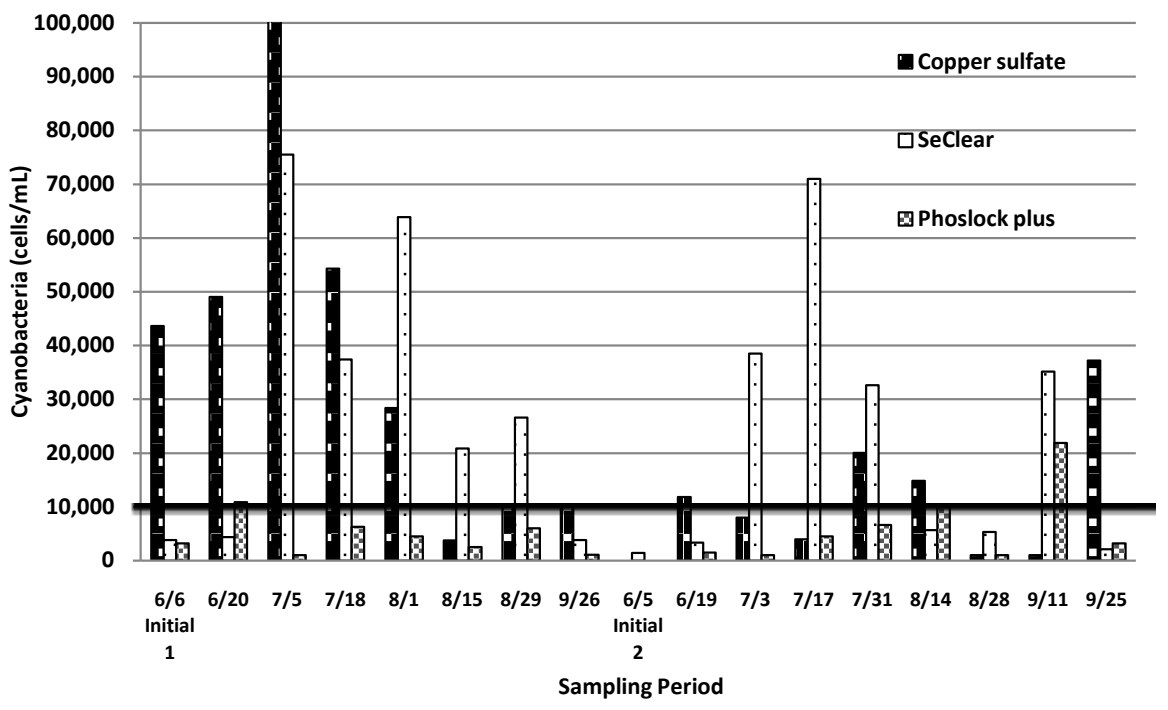

Figure 1. Average cyanobacterial cell densities in treatment ponds over two years. Line designates the algae action threshold level.

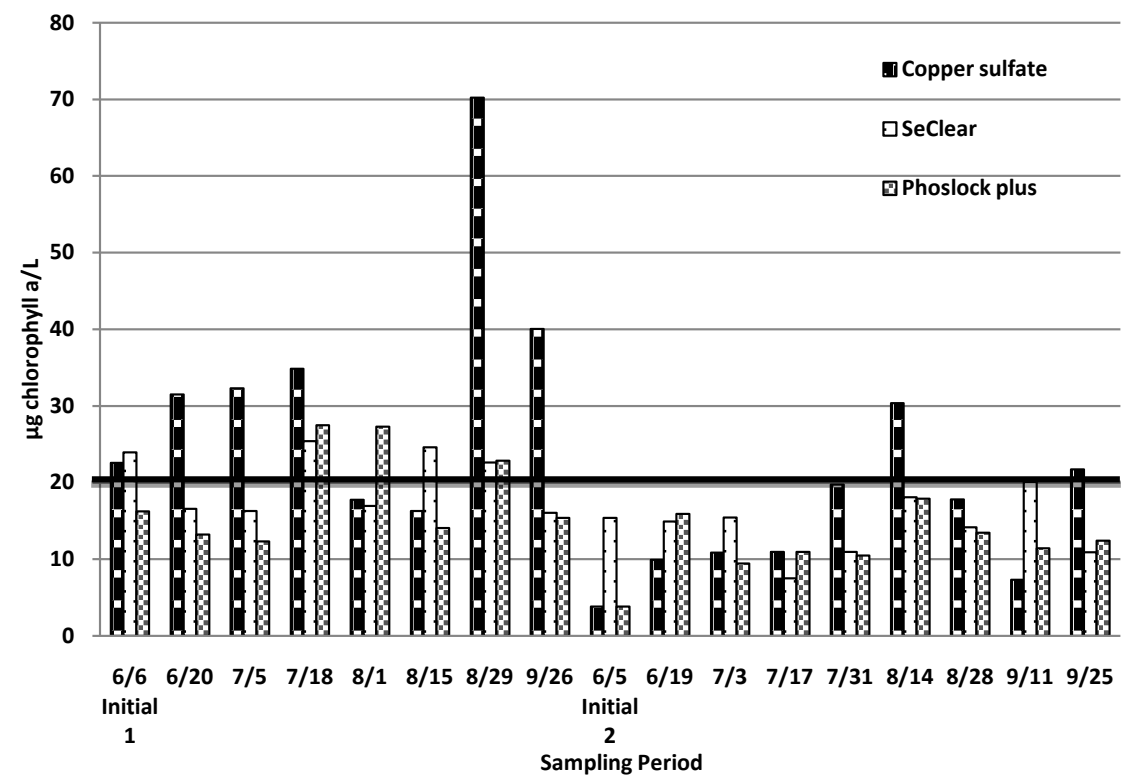

Figure 2. Average Chlorophyll $\alpha$ concentrations in treatment ponds over two years. Line designates the algae action threshold level. 
AATL $)$ and second year $(0$ AATL $)$ with the Phoslock plus program $(P=0.026)$. The continued use of Phoslock reduced the number of AATL exceeded in the subsequent year. Additionally, the number of chlorophyll $\alpha$ instigated AATL achieved with the copper sulfate was significantly greater than with the SeClear program $(\mathrm{P}=0.03)$. Total cell densities, Secchi depth and blue-green algae scum coverage were exceeded a total of 12 times across all treatment ponds with 10 coming from copper sulfate treatments and the other two from SeClear treated ponds. One Phoslock treated pond exceeded the green algal mat coverage AATL at the start of year two, although was maintained below the threshold level following a single reactive SeClear treatment. Overall $49 \%$ and $73 \%$ fewer AATL were exceeded (both significant at $\alpha=0.05$ ) in SeClear and Phoslock plus treatments, respectively compared with copper sulfate (Table 3 ).

\subsection{Water Quality Analyses}

Water quality analyses were similar at experiment initiation between all ponds and varied slightly throughout the study primarily based on evaporation and precipitation events as well as temperature. Ranges of water chemistries for all ponds were: conductivity $80-250 \mu \mathrm{S} \cdot \mathrm{cm}^{-1} ; 24-36^{\circ} \mathrm{C} ; 35-70 \mathrm{mg} \cdot \mathrm{L}^{-1}$ as $\mathrm{CaCO}_{3}$ for alkalinity and hardness); $<0.1 \mathrm{mg} \cdot \mathrm{L}^{-1}$ for nitrates/nitrites. Free reactive phosphorus levels remained low $\left(<10 \mu \mathrm{g} \cdot \mathrm{L}^{-1}\right)$ in all ponds throughout the treatment program. When phosphorus is a critical limiting nutrient, it is often assimilated rapidly into algae/bacteria biomass [24]. Treatment program analyses suggest that proactive technologies employed decreased the concentration of free reactive phosphorus. Despite a lack of difference observed in free reactive phosphorus levels due to low starting values, prior research has shown sediments can be a large sink/source of phosphorus in aquatic systems [25] [26] and many cyanobacteria have adaptations to allow uptake and storage of sediment associated phosphorus especially when limiting in epilimnetic waters [27] [28]. We hypothesize that the aqueous phosphorus measured was insufficient to capture the key available phosphorus sources in these systems and therefore, were unable to correlate decreases with the measured impacts on the resultant pond management program.

Table 3. Summary of pond management programs in terms of average number of algae action threshold levels exceeded, number of reactive algaecide treatments and total amount of elemental copper required to maintain ponds below action threshold levels. Results are an average of treatment replicates over a two-year period.

\begin{tabular}{cccc}
\hline & $\begin{array}{c}\text { Average number of } \\
\text { action thresholds exceeded } \\
\text { per year (Standard error) }\end{array}$ & $\begin{array}{c}\text { Average number of } \\
\text { reactive treatments per } \\
\text { year (Standard error) }\end{array}$ & $\begin{array}{c}\text { Average amount of } \\
\text { copper (g) needed per } \\
\text { year (Standard error) }\end{array}$ \\
\hline $\mathrm{CuSO}_{4}$ & 10.25 & 6.5 & 1,414 \\
& $(2.75)$ & $(0.5)$ & $(47.8)$ \\
SeClear & 5.25 & 4.25 & 829.5 \\
Phoslock & $(1.25)$ & $(0.25)$ & $(48.5)$ \\
plus & 2.75 & 1.75 & 341.5 \\
& $(0.75)$ & $(0.25)$ & $(48.5)$ \\
\hline
\end{tabular}




\subsection{Treatments and Copper Load}

Phosphorus removal is a critical component of shifting the N:P ratio in aquatic systems to select for more beneficial algal types as opposed to nuisance cyanobacteria [11] [12] [13]. This research sought to evaluate a standard approach to comparing pond management programs in order to discern whether integration of a preventative approach can provide operational, ecological, or economic advantages. In this research, copper sulfate only treated ponds required an average of 6.5 reactive treatments annually per pond whereas ponds treated with SeClear alone and Phoslock plus required 4.3 and 1.8 average treatments, respectively. There were significantly more treatments required with copper sulfate than either the SeClear and Phoslock programs $(\mathrm{P}=0.016)$. The amount of elemental copper necessary to be applied to ponds averaged $1414 \mathrm{~g}$ ( 3.12 pounds), $830 \mathrm{~g}$ ( 1.83 pounds), and $342 \mathrm{~g}(0.75$ pounds) for copper sulfate, SeClear, and Phoslock plus programs, respectively. Results were additionally consistent or continually improved from year one to year two in terms of decreased amount of treatments and elemental copper required in programs incorporating proactive management. Ponds treated with SeClear required an average of 31\% less number of algaecide applications year one and 39\% less year two compared with copper sulfate. Additionally, SeClear ponds needed $40 \%$ and $43 \%$ less elemental copper years one and two compared with copper sulfate. Pond treated with Phoslock plus SeClear required $69 \%$ and $77 \%$ less algaecide treatments than copper sulfate and $73 \%$ and $79 \%$ less elemental copper in years one and two, respectively. Ultimately, ponds treated with the copper sulfate program required significantly more applied copper than ponds treated with the SeClear or Phoslock plus programs, and the ponds treated with the Phoslock plus program required significantly less copper than the SeClear treated ponds $(\mathrm{P}=0.031)$.

\section{Conclusion}

Overall this research outlines a specific algae action threshold level approach for assessing and implementing water resource management programs. Action thresholds are based on management objectives and set in accordance with levels that preserve the designated uses of the water resource. This iterative, assessment-prescription-implementation approach is adaptable and can be tailored to different sites and encompass management of multiple types of nuisance algae/cyanobacteria. This research will also assist water resource managers in making informed decisions about incorporating technologies, other than strictly reactive algaecide products, into routine management. More specifically, the research findings support that integration of proactive nutrient mitigating technologies (e.g. Phoslock, SeClear) for addressing nuisance algal afflictions can decrease the number of reactive algaecide treatments and amount of algaecide entering aquatic systems, while maintaining the desired uses thereof.

\section{Acknowledgements}

The authors thank Scott Shuler, Shaun Hyde, Dr. Tyler Koschnick and Dr. Mark 
Heilman for valuable comments on experimental design. Nick Jackson assisted with sampling, and Ben Howard, Carey Barkley and Paige Denton contributed substantially with analytical support. The authors sincerely thank SePRO Corporation for use of their research campus and accredited laboratory to conduct this research.

\section{References}

[1] Hoagland, P., Anderson, D.M., Kaoru, Y. and White, A.W. (2002) The Economic Effects of Harmful Algal Blooms in the United States: Estimates, Assessment Issues, and Information Needs. Estuaries, 25, 819-837. https://doi.org/10.1007/BF02804908

[2] Hallegraeff, G.M. (1993) A Review of Harmful Algal Blooms and Their Apparent Global Increase. Phycologia, 32, 79-99. https://doi.org/10.2216/i0031-8884-32-2-79.1

[3] Paerl, H.W., Gardner, W.S., Havens, K.E., Joyner, A.R., McCarthy, M.J.J., Newell, S.E., Qin, B. and Scott, J.T. (2016) Mitigating Cyanobacterial Harmful Algal Blooms in Aquatic Ecosystems Impacted by Climate Change and Anthropogenic Nutrients. Harmful Algae, 54, 213-222. https://doi.org/10.1016/j.hal.2015.09.009

[4] United States Environmental Protection Agency (USEPA) (2011) National Pollutant Discharge Elimination System (NPDES). Pesticide General Permit (PGP) for Discharges from the Application of Pesticides. Washington, DC.

[5] Falconer, I.R. (1999) An Overview of Problems Caused by Toxic Blue-Green Algae (Cyanobacteria) in Drinking and Recreational Water. Environmental Toxicology, 14, 5-12. https://doi.org/10.1002/(SICI)1522-7278(199902)14:1<5::AID-TOX3>3.0.CO;2-0

[6] Carmichael, W.W., Azevedo, S.M.F.O., An, J.S., Molica, R.J.R., Jochimson, E.M., Lau, S., Rinehart, K.L., Shaw, G.R. and Eaglesham, G.K. (2001) Human Fatalities from Cyanobacteria: Chemical and Biological Evidence for Cyanotoxins. Environmental Health Perspectives, 109, 663-668. https://doi.org/10.1289/ehp.01109663

[7] Briand, J.F., Jacquet, S., Bernard, C. and Humbert, J.F. (2003) Health Hazards for Terrestrial Vertebrates from Toxic Cyanobacteria in Surface Water Ecosystems. Veterinary Research, 34, 361-377. https://doi.org/10.1051/vetres:2003019

[8] Webster, K.E. and Peters, R.H. (1978) Some Size-Dependent Inhibitions of Larger Cladoceran Filterers in Filamentous Suspensions. Limnology and Oceanography, 23, 1238-1245. https://doi.org/10.4319/lo.1978.23.6.1238

[9] Lampert, W. (1982) Further Studies on the Inhibitory Effect of the Toxic BlueGreen Microcystis aeruginosa on the Filtering Rate of Zooplankton. Archiv fur Hydrobiolgie, 95, 207-220.

[10] Wang, X., Qin, B., Gao, G. and Paerl, H.W. (2010) Nutrient Enrichment and Selective Predation by Zooplankton Promote Microcystis (Cyanobacteria) Bloom Formation. Journal of Plankton Research, 32, 457-470. https://doi.org/10.1093/plankt/fbp143

[11] Smith, V.H. (1983) Low Nitrogen to Phosphorus Ratios Favor Dominance by BlueGreen Algae in Lake Phytoplankton. Science, 221, 669-671. https://doi.org/10.1126/science.221.4611.669

[12] Seale, D.B., Boraas, M.E. and Warren, G.J. (1987) Effects of Sodium and Phosphate on Growth of Cyanobacteria. Water Research, 21, 625-631.

https://doi.org/10.1016/0043-1354(87)90072-8

[13] Ghadouani, A., Pinel-Alloul, B. and Prepas, E.E. (2003) Effects of Experimentally 
Induced Cyanobacterial Blooms on Crustacean Zooplankton Communities. Freshwater Biology, 48, 363-381. https://doi.org/10.1046/j.1365-2427.2003.01010.x

[14] Downing, J.A., Watson, S.B. and McCauley, E. (2001) Predicting Cyanobacteria Dominance in Lakes. Canadian Journal of Fisheries and Aquatic Sciences, 58, 1905 1908. https://doi.org/10.1139/f01-143

[15] Hrudey, S., Burch, S., Burch, M., Drikas, M. and Greorgy, R. (1999) Remedial Measures. In: Chorus, I. and Bartram, J., Eds., Toxic Cyanobacteria in Water, A Guide to Their Public Health Consequences, Monitoring and Management, Routledge, London.

[16] Douglass, G.B. (2002) Remediation Material and Remediation Process for Sediments. US Patent No. 6350383.

[17] Bishop, W.M., Hyde, S., McNabb, T., Cormican, I. and Willis, B.E. (2014) Operational Evaluation of Phoslock Phosphorus Locking Technology in Laguna Niguel Lake, California. Water, Air, and Soil Pollution, 225, 2018. https://doi.org/10.1007/s11270-014-2018-6

[18] Reitzel, K., Andersen, F.O., Egemose, S. and Jensen, H.S. (2013) Phosphate Adsorption by Lanthanum Modified Bentonite Clay in Fresh and Brackish Water. Water Research, 47, 2787-2796. https://doi.org/10.1016/j.watres.2013.02.051

[19] American Public Health Association (APHA) (2005) Standard Methods for the Examination of Water and Wastewater. 21st Edition, Washington, DC.

[20] SigmaPlot Version 12.3 (2013) Systat Software, Inc., San Jose, California.

[21] Twiss, M.R. and Nalewajko, C. (1992) Influence of Phosphorus Nutrition on Copper Toxicity to Three Strains of Scenedesmus acutus (Chlorophyceae). Journal of Phycology, 28, 291-298. https://doi.org/10.1111/j.0022-3646.1992.00291.x

[22] Guasch, H., Navarro, E., Serra, A. and Sabater, S. (2004) Phosphate Limitation Influences the Sensitivity to Copper in Periphytic Algae. Freshwater Biology, 49, 463 473. https://doi.org/10.1111/j.1365-2427.2004.01196.x

[23] Serra, A., Guasch, H., Admiraal, W., Van der Geest, H.G. and Van Beusekom, S.A.M. (2010) Influence of Phosphorus on Copper Sensitivity of Fluvial Periphyton: The Role of Chemical, Physiological and Community-Related Factors. Ecotoxicology, 19, 770-780. https://doi.org/10.1007/s10646-009-0454-7

[24] Jacobson, L. and Halmann, M. (1982) Polyphosphate Metabolism in the Blue-Green Alga Microcystis aeruginosa. Journal of Plankton Research, 4, 481-488. https://doi.org/10.1093/plankt/4.3.481

[25] Nürnberg, G. (1997) Coping with Water Quality Problems due to Hypolimnetic Anoxia in Central Ontario Lakes. Water Quality Research Journal of Canada, 32, 391-405.

[26] Søndergaard, M., Jensen, J.P. and Jeppesen, E. (2003) Role of Sediment and Internal Loading of Phosphorus in Shallow Lakes. Hydrobiologia, 506, 135-145. https://doi.org/10.1023/B:HYDR.0000008611.12704.dd

[27] Ganf, G.G. and Oliver, R.L. (1982) Vertical Separation of the Light and Available Nutrients as a Factor of Causing Replacement of Green Algae by Blue-Green Algae in the Plankton of a Stratified Lake. Journal of Ecology, 70, 829-844. https://doi.org/10.2307/2260107

[28] Barbiero, R.P. and Welch, E.B. (1992) Contribution of Benthic Blue-Green-Algal Recruitment to Lake Populations and Phosphorus Translocation. Freshwater Biology, 27, 249-260. https://doi.org/10.1111/j.1365-2427.1992.tb00537.x 
Submit or recommend next manuscript to SCIRP and we will provide best service for you:

Accepting pre-submission inquiries through Email, Facebook, LinkedIn, Twitter, etc. A wide selection of journals (inclusive of 9 subjects, more than 200 journals)

Providing 24-hour high-quality service

User-friendly online submission system

Fair and swift peer-review system

Efficient typesetting and proofreading procedure

Display of the result of downloads and visits, as well as the number of cited articles Maximum dissemination of your research work

Submit your manuscript at: http://papersubmission.scirp.org/

Or contact ojapps@scirp.org 